\title{
ОСОБЛИВОСТІ ЕМОЦІЙНИХ ПРОЯВІВ У ВИХОВАТЕЛІВ 3 РІЗНИМИ РІВНЯМИ ПРОФЕСІЙНИХ ДЕФОРМАЦІЙ
}

\section{Полішук Оксана Миколаӥвна}

Кандидат психологічних наук, доиент кафедри психології, Чернівецький національний університет імені Юрія Федьковича, м. Чернівці (Україна)

ORCID ID: https://orcid.org/0000-0003-1289-7428

\section{Колтунович Тетяна Анатолївна}

\begin{abstract}
Кандидат психологічних наук, асистент кафедри педагогіки та психології дошкільної освіти, Чернівеизький національний університет імені Юрія Федьковича, м. Чернівиі (Україна)

ORCID ID: http://orcid.org/0000-0003-4573-430X
\end{abstract}

\begin{abstract}
Анотація. У статті здійснено аналіз особливостей професійних деформацій, уточнено дефінітивну характеристику поняття «професійна деформація вихователя» та окреслено ключові детермінанти професійних деформаиій вихователів. Висвітлено результати емпіричного дослідження професійних деформацій у вихователів закладів дошкільної освіти, та їх зв'язку з емпатію, агресивністю та поведінкою у конфліктних ситуаціях. На основі отриманих результатів визначено, щь професійні деформачії вихователів закладів дошкільної освіти є доволі поширеним явищем; вихователям з високим рівнем професійних деформацій властиві незадоволеність власною професійною діяльністю, високі показники аутоагресій та гетероагресї̈, використання у конфліктних ситуачіях стилю суперництва. 3'ясовано, щуо на зростання рівня $і$ вираженості ознак професійної деформації у вихователів, впливають: зростання руйнівної активності щзодо самого себе; зниження уміння спільно обирати в конфліктній ситуації альтернативний варіант, зростання прагнення домогтися своӥх інтересів, зниження рівня задоволеності змістом і умовами своєї пращі, агресивне ставлення до інших.
\end{abstract}

Ключові слова: професійні деформації, професійне вигорання, агресивність, конфліктність. 
Постановка проблеми. Згідно зі статистичними даними, професійна діяльність сучасної людини займає майже три четвертих частини їі життя та здійснює неабиякий вплив на ii особистість. Якщо працівник має чітку позитивну мотивацію до праці, прагне творчо підходити до різних професійних ситуацій, усвідомлює недоліки своєї поведінки і професійної діяльності та постійно працює над їх виправленням, тоді професія стає цінною сферою життя, у якій людина може проявити себе, досягти успіху, i, яка стимулює до розвитку. Коли ж професійна діяльність є тягарем (у зв'язку з їі складністю, відсутністю необхідних для даної професії здібностей і вмінь, розуміння необхідності постійного професійного й особистісного самовдосконалення), то працівник починає працювати стереотипно, беземоційно, проявляючи ригідність, агресивність поведінки, що часто переноситься і на особисте життя. Такі негативні зміни особистості, що відбуваються у процесі і під впливом трудової діяльності, отримали термінологічне позначення - професійна деформація. Осмислення особливостей професійних деформацій, емпіричні дослідження можуть стати основою для відповідних психопрофілактичних і корекційних програм для допомоги особистості у подоланні професійних труднощів.

Проблема професійних деформацій вихователів закладів дошкільної освіти практично не вивчена. Їй присвячено поодинокі дослідження (С. Лічман), хоча актуальність iï оче- видна, оскільки саме особистість вихователя здійснює безпосередній вплив на розвиток дитини (iї знання, уявлення, погляди, вміння, навички, психічні якості та ін.), саме від нього залежить успішність адаптації дитини до навколишнього світу, повноцінний розвиток іiі особистості. Тоді як професійна деформованість вихователя впливає не тільки на його психічне і фізичне благополуччя, але й на його взаємини з оточуючими та є негативним прикладом для дітей.

\section{Аналіз останніх досліджень і публіка-}

цій. Проблема вивчення професійних деформацій та їх впливу на особистісний і професійний розвиток - це важливий науковий напрям у практичній психології, який має комплексний і міждисциплінарний характер.

Термін «professional deformation» вперше використав Х. Ландерок у праці «Професіоналізм: дослідження професійної деформації» (1915), надрукованій в «Американському журналі соціології». У його розумінні «Тривале виконання певної професії створює в окремій людині деформацію процесів мислення і деформацію здорової оцінки важливості своєї роботи в загальній роботі тієї групи, до якої належить ця людина» [92, c. 30].

До вітчизняної науки термін «професійна деформація» ввів П. Сорокін (1921), з метою позначення негативного впливу професійної діяльності на поведінку та переживання людини. Він був переконаний у 
величезній деформаційній ролі професійної діяльності, тому запропонував першу соціологічну програму вивчення професійних деформацій [78, с. 334].

У вітчизняній науці радянського періоду вважалося, що «праця здійснює тільки позитивний вплив на особистість» [7, с. 82], тому в цей період вивченням (дослідженням) проблеми професійних деформацій практично не займалися. Тільки в кінці XX ст. психологи (Е. М. Борисова, Р. М. Грановська, Е. Ф. Зеєр, А. К. Маркова та ін.) почали доводити те, що не завжди праця сприяє гармонійному розвитку психіки людини; поширеними є варіанти, коли праця не збагачує особистість, а, навпаки, деформує $\dddot{1}$.

3-поміж вітчизняних вчених, які займалися і займаються проблемою професійної деформації особистості, вважаємо за необхідне назвати С. П. Безносова, Л. М. Корнєєву, А. О. Крилова, Е. С. Кузьміна, Б. Д. Новікова, М. М. Обозова, С. І. Рогова та ін.

Зокрема, С. П. Безносов наголошує, що професійна діяльність, в силу іiі специфіки, володіє більш потужним трансформуючим i деформуючим впливом на особистість, ніж непрофесійні види праці [6, с. 11].

Основна увага зарубіжних вчених спрямована на вивчення такого феномена професійної діяльності, як професійне вигорання, яке часто пов'язують 3 професійними деформаціями. У наш час існує багато найрізноманітніших теоретичних підходів в описі цього явища (Х. Дж. Френдербергер, К. Маслач i С. Джексон, К. Кондо, В. О. Орел, А. Пайнс і ін.) [12, с.7]. 3-поміж вітчизняних психологів, які займаються розробкою цієї проблеми, слід відзначити

Н. Є. Водоп'янову,

Т. В. Зайчикову, Є. М. Іванову,

Л. М. Карамушку, В. О. Орла,

О. О. Рукавішнікова, О. С. Старченко, Т. В. Форманюк та ін. Зокрема, психічні стани у трудовій діяльності досліджували: В. С. Агапов, О. С. Анісімов, С. П. Безносов, Р. М. Грановська, А. О. Деркач, С. О. Дружилов, В. Г. Зазикін, Е. Ф. Зеєр, Є. О. Климов, Н. В. Кузьміна, А. К. Маркова, Л. М. Мітіна, М. С.Пряжников, С. I. Рогов, Ю. В. Синягин, І. А. Хоменко та ін. В методичному і практичному плані проблема вигорання виявилась більш розробленою, в порівнянні 3 дослідженнями професійної деформації особистості. Це пов'язано з тим, що синдром вигорання, який розглядається в контексті професійної діяльності, може виникати на самому початку професійного шляху та завдяки своєму емоційному компоненту постійно нагадувати особистості про стан незадоволеності результатами праці, викликаючи бажання змінити стан справ, тоді як професійні деформації проявляються на більш пізніх етапах професійного становлення і не завжди усвідомлюються суб' єктом.

У наш час дослідження професійних деформацій, їх причин і наслідків відбувається переважно у рамках дослідження професій- 
ного вигорання як одного з їх проявів.

Множинні уявлення про зміст професійних деформацій, наявність численних дескрипторів і дефінітивних характеристик цього явища, відсутність єдиного підходу до розуміння їх основних симптомів і чинників, критеріїв відмежування професійних деформацій від подібних станів значно ускладнюють їх діагностику, профілактику та корекцію.

Мета роботи. Теоретично обгрунтувати та емпірично вивчити особливості емоційних проявів у вихователів з різними рівнями професійних деструкцій. Визначити ключові детермінанти професійних деформацій вихователів.

Виклад основного матеріалу. У науковій літературі не існує єдиного трактування поняття «професійна деформація». Її тлумачать, виходячи з різних підходів, як захворювання, порушення, загострення певних особистісних характеристик, наслідок втоми, стресу тощо.

Численні теоретичні доробки та емпіричні дослідження професійних деформацій i деструкцій особистості у представників різних професій (вчителів, працівників правоохоронних органів, психологів, медичних і соціальних працівників здійснено С. П. Безносовим, Е. Ф. Зеєром, А. О. Криловим, Л. М. Корнєєвою, А. К. Марковою, В. Д. Небиліциним, О. М. Новиковим, М. М. Обозовим, Е. Е. Симанюк та ін. Проблеми збереження професійного здоров'я та профілактики професійних деформацій вивчали В. А. Пономаренко, В. І. Шостак, Л. А. Яньшин, А. Н. Разумов, А. Г. Маклаков i iн.

Усі погляди вчених на проблему професійних деформацій можна умовно згрупувати у два підходи. Перший акцентує увагу на адаптації особистості до вимог професії, підлаштуванні до заданого зразка, як єдиного можливого в даній професії, на виробленні професійно важливих рис (теорія «рис і чинників» Ф. Парсонса, «професійного вибору» Дж. Холланда) [17; 18]. Другий підхід побудований на припущенні, що професія обирається, виходячи з наявності в особистості певних якостей і установок, але в той же час кожна професія накладає специфічний відбиток на психічний образ людини (D. Super, A. Roe) $[19 ; 20 ; 21 ; 22]$.

Розглянемо кілька найбільш поширених дефінітивних характеристик поняття. Е. Зеєр трактує професійну деформацію як професійне захворювання [9; 10]; О. Рубін та С. Смирнов - як зміни (порушення) структури, цілісності особистості, що призводять до зниження рівнів адаптації та ефективності професійного функціонування, звуження кола інтересів і потреб до виключно професійних [14]; С. Геллерштейн та О. Рукавішніков - як відхилення від певного соціального орієнтира, норми, професійної вимоги, які спричинені професійною роботою, що призводять до стійких змін у поведінці і діяльності [7; 13]. 
В. Бойко та О. Юрченко наголошують на деформуючому впливі окремих професій та визначають деформацію педагога як дисгармонізацію його особистості, спричинену педагогічною діяльністю [5; 16].

У розумінні Г.Грановської [8] i С. Геллерштейна [7], деформація є наслідком негативного впливу професійної діяльності на формування в особистості стійких зразків поведінки та мислення, на психологічні характеристики людини, що утруднює iї поведінку в повсякденному непрофесійному житті. Є. Борисова висвітлює захисну функцію професійної деформації, трактуючи останню як своєрідну компенсацію у фахівців, які не володіють достатнім рівнем професійних здібностей і творчим моментом в роботі [4].

О. Марковець пов'язує професійну деформацію з професійним стресом і його наслідками [12].

Л. М. Корнєєва вважає, що професійна деформація носить компенсаторний характер і більш характерна для людей 3 недостатнім рівнем професійних здібностей і відсутністю творчого моменту в діяльності [11].

Р. М. Грановська пише, що профдеформація виявляється в особливостях установки та стереотипах поведінки працівника і утруднює спілкування: «Одна із форм деформації проявляється у виникненні хибного уявлення, що і без нових знань накопичені стереотипи забезпечують необхідну швидкість, точність і успішність діяльності. Закріплюється зайва трафаретність в підходах, спрощеність в поглядах на робочі проблеми, що призводить до зниження професійного рівня спеціаліста, його деградації. Інша сторона деформації проявляється в перенесенні профзвичок, корисних на роботі, на дружнє і сімейне спілкування. Під час автоматизації дій образи, які регулюють процес діяльності, стають усе більше узагальненими, економічними, швидкими та неусвідомленими» [8, с. 202].

В результаті дослідження трудового процесу С. П. Безносовим [2] доведено наявність деформуючого впливу на людину кожного елементу структури професійної діяльності: іiі предмета, процесів його перетворення, продукту праці, засобів діяльності, способів їх застосування, здібностей суб'єктапрофесіонала. Зокрема, щодо впливу предмета й об’єкта діяльності на людину він пише: «Методологічно ясно, що той спеціальний об'єкт праці, над яким постійно трудиться професіонал протягом своєї кар'єри, вимушено заповнює значну частину його свідомості, по відношенню до нього (і своїх потреб, звичайно) він відчуває різні психологічні переживання. Цей предмет праці споживає робочий час, фізичну, нервову, психічну енергію діяча. Саме він значний час життя знаходиться в центрі уваги, насамперед, суб'єкта діяльності, а вже потім і особистості, всієї індивідуальності людини. Саме предмет трудових зусиль сковує залізним ланцюгом зміст свідомості спеціаліста протягом робочого часу (за ви- 
ключенням перерв на обід, відпочинок тощо). Об'єкт діяльності є могутнім чинником (де) формування людини, iiï особистості» [2, с. 4849].

У концепціях професійного становлення i розвитку особистості В. А. Бодрова, Е. Ф. Зеєра, С. О. Климова, А. К. Маркової, Л. М. Мітіної та ін. визнається різноспрямованість онтогенетичних змін у процесі виконання професійної діяльності. Авторами відзначений дихотомічний характер впливу професії на формування та розвиток особистості. 3 одного боку, професійна діяльність позитивно впливає на психіку людини, задає напрям розвитку особистості, формує найважливіші сторони іiі індивідуальності, а з іншого - чинить негативний вплив на особистість, порушуючи iï цілісність, знижуючи адаптивність і стійкість.

Отже, професійні деформації - це порушення вже засвоєних способів діяльності, руйнування сформованих професійних якостей, поява стереотипів професійної поведінки та психологічних бар'єрів у процесі оволодіння новими професійними технологіями, новою професією чи спеціальністю; це зміни структури особистості при переході від однієї стадії професійного становлення до іншої.

На основі здійсненого теоретичного аналізу детермінант професійних деформацій у педагогів можна звести їх до трьох груп: об'єктивні (непопулярність професії, низька заробітна плата, неналежні матеріально- технічне забезпечення та умови для саморозвитку, глобальне реформування системи і програми освіти, високі вимоги й очікування з боку суспільства, стаж роботи, фемінізованість педагогічних колективів); суб'єктивні (високий рівень відповідальності, тривожність, конфліктність, інфантильність, песимізм, відсутність комунікативних і організаційних умінь, конфліктної компетентності, гетеро та аутоагресія, низький рівень емпатії, неусвідомлювані або прагматичні мотиви вибору професії, нереалістичні очікування на стадії входження в самостійне професійне життя, утворення стереотипів здійснення професійних функцій, дій, операцій, різні форми психологічного захисту (заперечення, раціоналізація, витіснення, проекція, ідентифікація, відчуження), стагнація професійного розвитку (виникає при монотонній, одноманітній, жорстко структурованій роботі), зниження рівня інтелекту, прагнення до саморозвитку, психологічне насичення професійною діяльністю, незадоволеність іміджем професії, низькою зарплатою, відсутність моральних стимулів, акцентуації характеру (демонстративність, педантичність, застрягання, збудливість, гіпертимність, тривожність, циклотимність, екзальтованість, емотивність), несприйнятливість до нововведень, канонізація індивідуального досвіду та досвіду свого покоління); об'єктивно-суб'єктивні (постійна емоційна напруга, висока інтенсивність праці, хронічний дефіцит часу, відсутність необхідної свободи у процесі вироблення та прийняття 
рішень, професійні стреси, конфліктні ситуації 3 колегами, батьками вихованців, неадекватні винагороди та підтримка 3 боку керівників, надмірно ліберальний або авторитарний стиль керівництва, постійні та невиправдані ротації, зміни, переміщення, робота 3 дітьми (сприяє формуванню схильності до спрощення, роз'яснення), неоднорідність контингенту дітей і батьків, з якими слід ефективно співпрацювати, відсутність права на помилку, часу на розваги чи відпочинок, постійне перебування у стані контролюючого дорослого 3 високим рівнем відповідальності за життя і здоров'я вихованців, особистісна невлаштованість, порушення балансу «робота-особисте життя»).

Таким чином, до ключових детермінант професійних деформацій вихователів можна віднести: відсутність комунікативних навичок, здатності до саморефлексії та саморелаксації; контингент (діти, батьки, колеги, адміністрація) та потребу в ефективній взаємодії з усіма; роботу $з$ дітьми (сприяє формуванню схильності до спрощення, роз'яснення); низький престиж професії; стаж роботи; фемінізованість колективу; відсутність права на помилку, часу на розваги чи відпочинок, постійне перебування у стані контролюючого дорослого 3 високим рівнем відповідальності за життя і здоров'я вихованців, що супроводжується пригніченням власних емоцій, станів і їх проявів задля благополуччя інших, особистісну невлаштованість, порушення балансу «робота-особисте життя».

Емпіричне дослідження професійних деформацій у вихователів проводилось на базі шести закладів дошкільної освіти м. Чернівці, факультету педагогіки, психології та соціальної роботи Чернівецького національного університету імені Юрія Федьковича (серед студентів які працюють у закладах дошкільної освіти).

Обсяг вибірки на емпіричному етапі дослідження склав 100 досліджуваних віком від 22 до 58 років (середній вік - 36,5 р.), зі стажем роботи від 1 до 40 років (середній стаж 15,2 p.).

При формуванні комплексу методик було відібрано ті, які повною мірою, грунтовно та всебічно розкривають предмет дослідження: «Опитувальник на професійне вигорання та деформацію» (MBI) у модифікації О. Полякової (для визначення рівня вираженості професійних деформацій та їх складових: емоційного виснаження, деперсоналізації, редукції особистих досягнень); «Методику діагностики емпатійних здібностей» В. В. Бойка (для виявлення загального рівня емпатії та визначення іiі домінуючого каналу); методикк «Вивчення задоволення педагогів своєю професією та роботою», розроблену М. В. Журіним і Є. П. Ільїним (для виявлення ступеня задоволеності вихователів своєю професією і різними сторонами професійної діяльності); методику «Професійна деформація педагогів» Є. П. Ільїна (для визначення рівня сформованості професійних деформацій у вихователів); методику А. Ассингера 
«Діагностика схильності до агресивної поведінки» (для виявлення рівня агресивності у педагогів, вміння коректно поводитися і спілкуватися з оточуючими); опитувальник «Ауто- i гетероагресія» Є. П. Ільїна (для визначення спрямованості агресії особистості); методику К. Н. Томаса «Оцінка типового стилю конфлі-
Зауважимо, що вираження показників не тяжіє до межових значень (СД ${ }_{\text {min. }}=56$ б., СД $Д_{\text {max. }}=95$ б.), та, відповідно до ключа методики, відображає початковий етап формування конструкту «емоційне виснаження» $(23,6$ б.) та конструкту «деперсоналізація» $(10,6$ б.), заключний етап формування конструкту «редукція

Таблиия 1.

Усереднені показники сформованості компонентів професійної деформації у вихователів $(\mathbf{n}=\mathbf{1 0 0})$

\begin{tabular}{|c|c|c|c|}
\hline \multirow{2}{*}{ Компонент } & \multicolumn{3}{|c|}{ Показник сформованості, б. } \\
\cline { 2 - 4 } & низький & середній & високий \\
\hline емоційне виснаження & 14,8 & 23,6 & 42,2 \\
\hline деперсоналізація & 6,3 & 11,7 & 23,2 \\
\hline редукція особистих досягнень & 40,2 & 30 & 17,5 \\
\hline $\begin{array}{c}\text { загальний показник професійної } \\
\text { деформації }\end{array}$ & 56,67 & 69,22 & 96,25 \\
\hline
\end{tabular}

ктної поведінки» в модифікації Н. В. Грішиної (для виявлення типового способу реагування на конфліктні ситуації: суперництво, співробітництво, компроміс, уникнення, пристосування). Для обрахування отриманих даних використовувались методи описової статистики, кореляційний аналіз r-Spearman, Н-критерій Крускалла-Уолліса.

Узагальнення даних, отриманих за допомогою «Опитувальника на професійне вигорання та деформацію» (MBI) у модифікації О. Полякової, показало, що вибіркове середнє підсумкового показника сформованості деформації (надалі - СД) по вибірці в цілому склало 67,5 б. із 132 максимально можливих. особистісних досягнень» $(33,1$ б.) (Табл.1).

У цілому по вибірці високий рівень професійної деформації виявлено у 16\% досліджуваних, середній - у $72 \%$, низький - у $12 \%$ (Рис. 1).

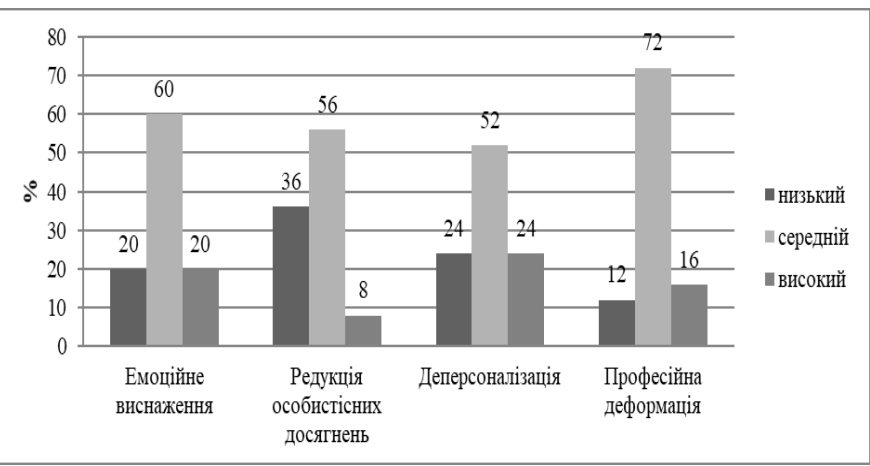

Рис.1. Рівні сформованості емоційного вигорання та професійної деформації, \% (N=100) 
У групі досліджуваних з високим рівнем професійної деформації на високому рівні сформовані конструкти «емоційне виснаження» $(\mathrm{M}=44,8)$ та деперсоналізація $(\mathrm{M}=24,5)$, натомість конструкт «редукція особистісних досягнень» перебуває на середньому рівні $(\mathrm{M}=27)$.

У групі з середнім рівнем професійної деформації «емоційне виснаження» 5,56 \% досліджуваних - на високому рівні, у $77,78 \%$ - на середньому і у $16,67 \%$ - на низькому; «редукція особистісних досягнень» не сформована і знаходиться на низькому рівні у 44,44\% досліджуваних, у 55,56 \% - починає формуватися і перебуває на середньому рівні; «деперсоналізація» - у 77,8 \% досліджуваних перебуває на середньому рівні, у 22,2\% - на низькому.

Дані досліджуваних 3 низьким рівнем професійної деформації вказують на низький рівень «емоційного виснаження» $\mathrm{i}$ «деперсоналізації» у 66,7 \% досліджуваних, у 33,3 \% - середній рівень; «редукція особистісних досягнень», навпаки, перебуває на середньому рівні у 66,7 \% досліджуваних, у $33,3 \%$ - на низькому.

Отже, для вихователів закладів дошкільної освіти з високим і середнім рівнями професійної деформації характерні: втрата інтересу та позитивного ставлення до вихованців і інших учасників навчально-виховного у зв'язку з відчуттям «перенасиченості» роботою, незадоволеністю життям в цілому, психофізич- ною перевтомою; розвиток емоційної відмежованості та байдужості, формального виконання професійних обов'язків без особистісної включеності і співпереживання, а в окремих випадках прояв негативізму і цинічного ставлення до колег, дітей та їхніх батьків. У вихователів з низьким рівнем професійної деформації перелічені симптоми проявляються вкрай рідко, натомість починає розвиватися негативне оцінювання себе, своїх професійних досягнень, якостей і можливостей, обмеження своєї відповідальності і перекладання іï на інших (керівництво, колег, батьків вихованців) тощо.

Показники, отримані за методикою «Професійна деформачія педагогів» свідчать, що 25\% досліджуваних мають низький рівень професійної деформації, 45\% - середній рівень та $30 \%$ високий.

На основі результатів, отриманих за двома методиками, досліджуваних було розділено на три групи за критерієм «рівень сформованості професійних деформацій» - групу з високим рівнем професійної деформації, середнім і низьким.

Результати, отримані за допомогою «Методики діагностики рівня емпатійних здібностей» В. В. Бойко в трьох групах досліджуваних, свідчать про низький рівень емпатії у більшості вихователів (70\%). Середній та високий їі рівні діагностовано у $25 \%$ та у $5 \%$ досліджуваних відповідно.

За даними методики «Вивчення задоволення педагогів своєю професією та робо- 
тою» у 55\% вихователів виявлено середній рівень задоволення професійною діяльністю $(\mathrm{M}=10,6)$, у 45\% - високий $(\mathrm{M}=4,1)$, у 70\% досліджуваних діагностовано низький ступінь незадоволеності роботою, а у $30 \%$ - середній (Рис. 2)
Результати, отримані за опитувальником «Аутоагресія $i$ гетероагресія» свідчать про переважання гетероагресії (спрямування агресії на оточуючих) у 15 \% досліджуваних, та аутоагресії (спрямування агресії на себе, самозвинувачення) у 85 \% вихователів (Рис.3).

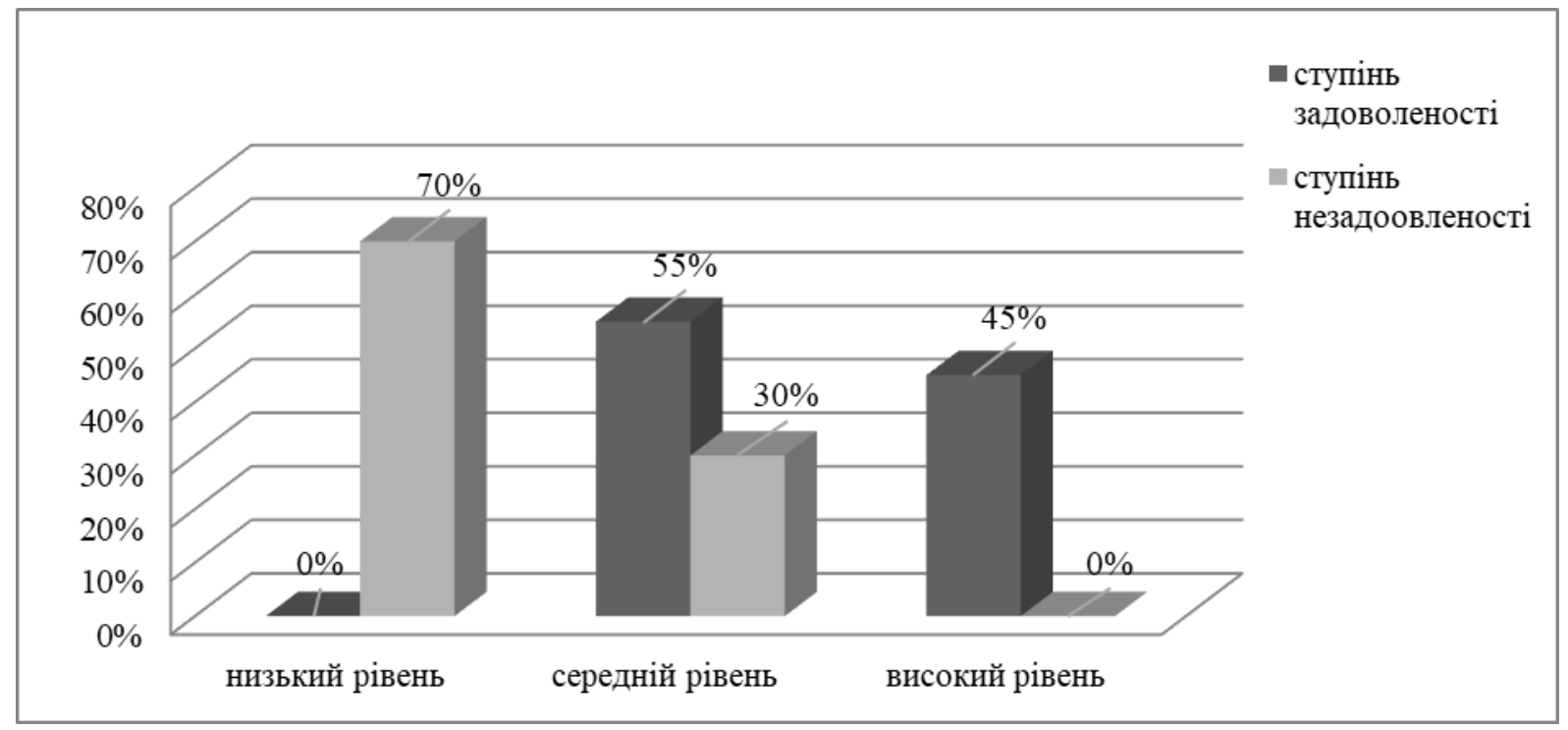

Рис.2. Ступінь задоволеності/незадоволеності професісю, \%

Найбільш типовими варіантами поведінки вихователя невдоволеного своєю роботою $\epsilon$ апатія, втеча від дійсності, громадська пасивність, або ж наростання агресивності тощо. Варто зазначити, що у вихователів з високим рівнем професійної деформації переважає незадоволеність професією (M=6,75), а у вихователів з середнім і низьким рівнями, навпаки, переважає задоволеність ( $\mathrm{M}=10,9$ та $\mathrm{M}=10,3$, відповідно).

Тому наступним кроком дослідження була діагностика агресії та аутоагресії як чинників професійної деформації у вихователів закладів дошкільної освіти.
Отримані показники вказують на наявність у більшості досліджуваних низької самооцінки, незадоволеності самореалізацією, емоційної нестабільності, невпевненості у міжособистісних стосунках. Так, у групі вихователів з високим рівнем професійної деформації середні показники аутоагресії $(\mathrm{M}=88,5)$ вищі, аніж показники гетероагресії $(\mathrm{M}=79)$. У групі 3 середнім рівнем професійної деформації, навпаки, вищими є середні показники гетероагpeciї $(\mathrm{M}=47,6)$, у порівнянні 3 аутоагресією $(\mathrm{M}=45,1)$, що може бути пов'язаним 3 переважанням конструкту деперсоналізації у цій групі. Переважання аутоагресії $(\mathrm{M}=32,5)$ спосте- 


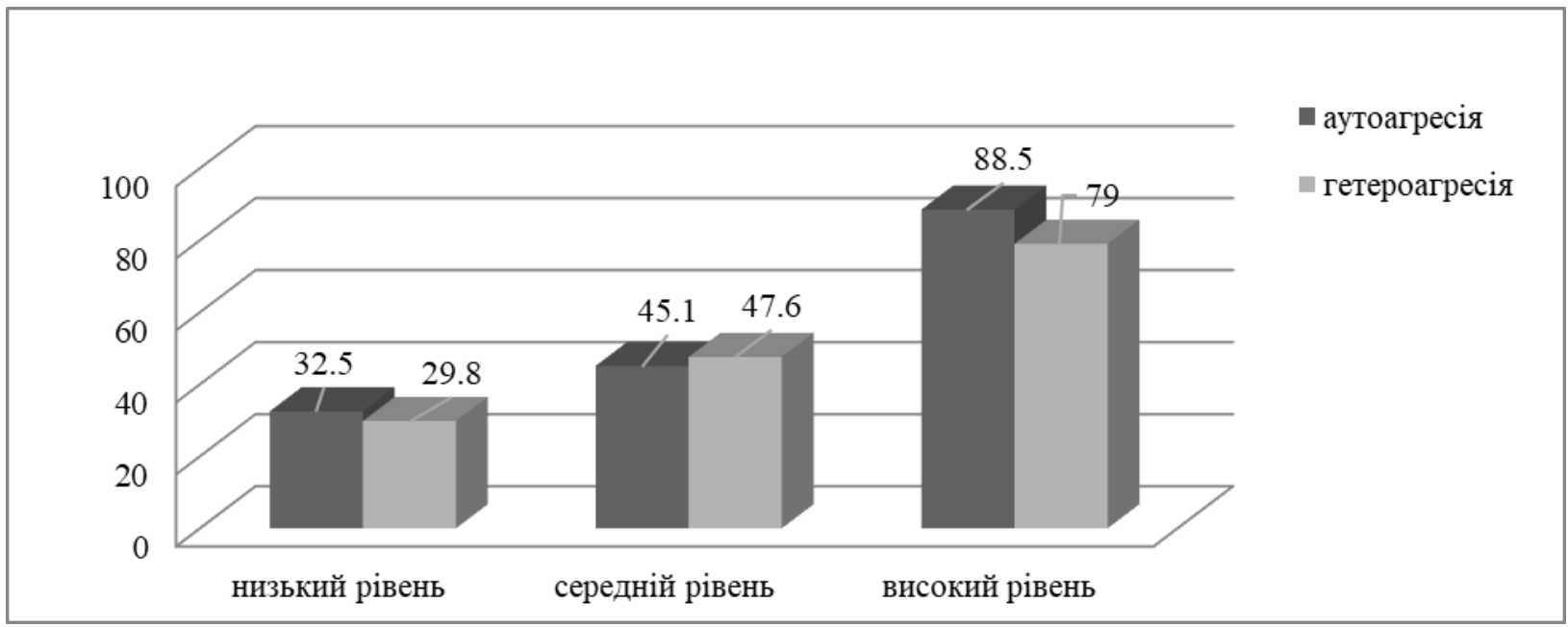

Рис. 3. Схильність до аутоагресії чи гетероагресії, М

рігається і у вихователів з низьким рівнем професійної деформації.

\section{Дані методики А. Ассингера} "Діагностика схильності до агресивної поведінки» вказують, що 20\% вихователів помірно статньо честолюбні і самовпевнені; 80\% вихователів миролюбні, недостатньо агресивні, що часто є свідченням невпевненості у своїх силах і можливостях, невміння захистити свої інтереси (Рис.4).

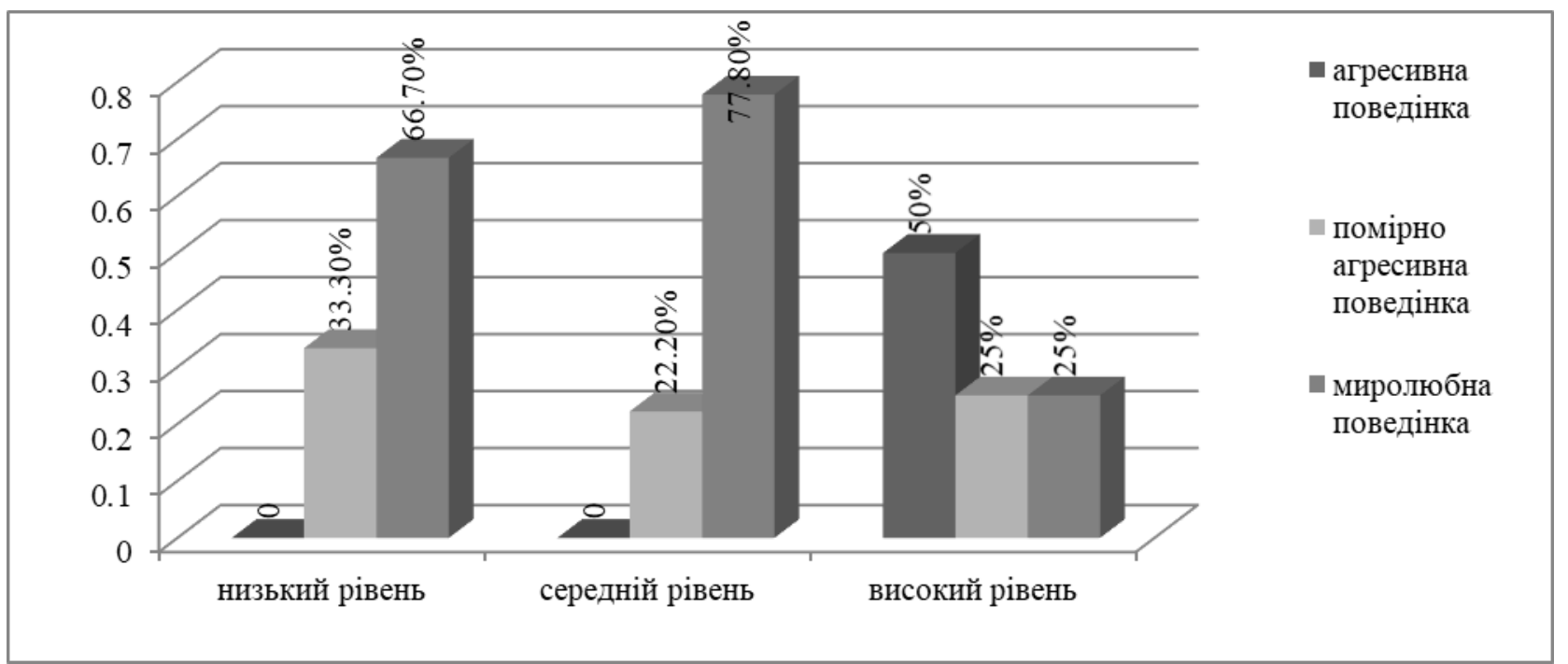

Рис. 4. Схильність до агресивної поведінки, \%

агресивні, тобто здатні постояти за себе, до-

У досліджуваних 3 високим рівнем 
професійної деформації переважає агресивна поведінка (50\%), наступні позиції займають помірно агресивна (25\%) та миролюбна поведінка (25\%). У 77,8\% досліджуваних із середнім рівнем професійної деформації переважає миролюбна (пасивна) поведінка, у решти 22,2\% вихователів - помірно агресивна. Вихователі з низьким рівнем професійної деформації також більш схильні до миролюбної поведінки $(66,7 \%)$, аніж до помірно агресивної $(33,3 \%)$

Таким чином, у вихователів з високим рівнем професійної деформації спостерігається високий рівень агресивної поведінки щодо оточуючих, тобто вони все частіше використовують пряму та непряму форми агресії (фізичні покарання, словесне приниження, грубе звертання, крики, погрози, спілкування у формі розпоряджень, відмова спілкуватися, демонстрування підозріливості і образливості, антипатія або відразливе ставлення до деяких дітей - неохайних, з відхиленнями у розвитку або поведінці).

У групі вихователів 3 середнім і низьким рівнем професійної деформації переважає миролюбна поведінка, що, у певних ситуаціях, теж виступає деформуючим чинником, адже свідчить про невпевненість у своїх силах і можливостях, невміння захистити свої інтереси.

Результати за методикою «Оиінка типового стилю конфліктної поведінки» у групі досліджуваних з високим рівнем професійної деформованості 75\% вихователів найчастіше використовують у конфліктній ситуації стиль суперництва, а інші 25\% - стиль уникнення. Вихователі з середнім рівнем професійної реформованості обирають здебільшого стиль компромісу $(24,3 \%)$, пристосування $(24,3 \%)$ та уникнення (22,9\%). Стиль суперництва використовують $17,2 \%$, а стиль співпраці - $11,4 \%$ досліджуваних.

Група 3 низьким рівнем професійної деформованості характеризується використанням майже всіх стилів конфліктної поведінки: у 33,3\% досліджуваних переважають стилі співпраці та пристосування, 33,3\% вихователів обирають, залежно від ситуації, стилі співпраці, компромісу і пристосування, а решта $33,3 \%$ - стиль уникнення.

3 метою виявлення взаємозв'язків між досліджуваними показниками у трьох групах досліджуваних емпіричні дані було піддано кореляційному аналізу за допомогою коефіцієнта рангової кореляції Спірмена $\left(r_{S}\right)$ (Табл. 2).

У зв'язку з наявністю значної кількості статистично значущих взаємозв'язків, було проаналізовано тільки найбільш значущі $(\mathrm{p} \leq 0,01)$. Як видно з табл. 2, зворотні кореляційні зв'язки виявлено між рівнем професійної деформації i: стилем поведінки у конфлікті «співпраця» $(\mathrm{r}=-0,643)$; стилем компромісу $(\mathrm{r}=-0,589)$; стилем співпраці $(\mathrm{r}=-0,526)$ ступенем задоволення роботою $(\mathrm{r}=-0,463)$; стилем пристосування (r=-0,363), тобто невміння оби- 
Матриця інтеркореляційних зв'язків станів і властивостей особистості

та професійних деформацій

\begin{tabular}{|c|c|c|c|c|c|}
\hline $\begin{array}{c}\text { Емоційно-поведінкові } \\
\text { конструкти }\end{array}$ & $\begin{array}{c}\text { Висна- } \\
\text { ження }\end{array}$ & $\begin{array}{c}\text { Деперсо- } \\
\text { налізація }\end{array}$ & Редукція & $\begin{array}{c}\text { Професій- } \\
\text { на дефор- } \\
\text { мація }\end{array}$ & $\begin{array}{c}\text { Рівень } \\
\text { професій- } \\
\text { ної дефор- } \\
\text { мації }\end{array}$ \\
\hline рівень емпатії &, 005 &, 041 &, $261^{* *}$ &, 156 &,$- 214^{*}$ \\
\hline ступінь задоволення &,$- 640^{* *}$ &,$- 561^{* *}$ &, $595^{* *}$ &,$- 338^{* *}$ &,$- 463^{* *}$ \\
\hline ступінь незадоволення &, $308^{* *}$ &, $431^{* *}$ &,$- 322^{* *}$ &, $237^{*}$ &, $481^{* *}$ \\
\hline аутоагресія &, $474^{* *}$ &, $552^{* *}$ &,- 105 &, $633^{* *}$ &, $464^{* *}$ \\
\hline гетероагресія &, $316^{* *}$ &, $669^{* *}$ &,$- 325^{* *}$ &, $442^{* *}$ &, $437^{* *}$ \\
\hline агресивна поведінка &, 093 &, $330^{* *}$ &,- 166 &, $202^{*}$ &, $358^{* *}$ \\
\hline суперництво &, $295^{* *}$ &, $561^{* *}$ &,$- 382^{* *}$ &, $317^{* *}$ &, $463^{* *}$ \\
\hline співпраця &,$- 385^{* *}$ &,$- 476^{* *}$ &, 151 &,$- 526^{* *}$ &,$- 643^{* *}$ \\
\hline компроміс &,$- 358^{* *}$ &,$- 479^{* *}$ &, $331^{* *}$ &,$- 326^{* *}$ &,$- 589^{* *}$ \\
\hline уникнення &, 122 &,- 113 &,- 050 &,- 063 &, 023 \\
\hline пристосування &,$- 295^{* *}$ &,$- 432^{* *}$ &, $315^{* *}$ &,$- 242^{*}$ &,$- 363^{* *}$ \\
\hline
\end{tabular}

рати альтернативні варіанти поведінки, йти на поступки, відсутність прагнення поступатися власними інтересами заради іншого, зниження ступеня задоволеності змістом і умовами своєї роботи, супроводжуються зростанням рівня професійної деформації.

Прямі статистично значущі кореляційні взаємозв'язки виявлено між: рівнем професійної деформації i: рівнем емпатії $(\mathrm{r}=0,669)$, рівнем аутоагресії $(\mathrm{r}=0,633)$, ступенем незадоволення роботою $(\mathrm{r}=0,481$,$) , аутоагресією$ $(\mathrm{r}=0,464)$, стилем суперництва $(\mathrm{r}=0,463)$, гетероагресією $(\mathrm{r}=0,442)$, агресивною поведінкою $(\mathrm{r}=0,358)$, стилем суперництва $(\mathrm{r}=0,317)$, тоб- то зростання емоційної чутливості людини до переживань іншої людини, а також співпереживання, руйнівної активності щодо самого себе, ступеня незадоволеності змістом і умовами своєї роботи, зростання прагнення домогтися своїх інтересів незважаючи на потреби інших, агресивного ставлення і поведінки щодо оточуючих, супроводжується зростанням рівня професійної деформації.

Здійснення одностороннього дисперсійного аналізу Крускалла-Уолліса (Табл. 3) вказує на наявність статистично значущих відмінностей між групами вихователів з різними рівнями професійних деформацій за та- 
кими показниками: ступінь задоволеності/ незадоволеності роботою $(\mathrm{H}=37,748$ та $\mathrm{H}=15,775$, відповідно, при $\mathrm{p} \leq 0,01)$, аутоагресія $(\mathrm{H}=35,295, \mathrm{p} \leq 0,01)$, гетероагресія $(\mathrm{H}=23,507$, $\mathrm{p} \leq 0,01)$, агресивна поведінка $(\mathrm{H}=22,614$, $\mathrm{p} \leq 0,01)$, суперництво $(\mathrm{H}=32,823, \mathrm{p} \leq 0,01)$, співпраця $\quad(\mathrm{H}=14,979, \quad \mathrm{p} \leq 0,01), \quad$ компроміс $(\mathrm{H}=13,3434, \quad \mathrm{p} \leq 0,01) \quad$ та пристосування нім і низьким іiі рівнями.

У вихователів з високим рівнем професійних деформацій незадоволеність власною професійною діяльністю статистично вища $(\mathrm{H}=15,775, \mathrm{p} \leq 0,01)$, ніж у вихователів 3 середнім рівнем.

У вихователів з високим рівнем професійних деформацій статистично значущо вищі

Таблиия 3.

\section{Порівняння груп вихователів 3 різними рівнями професійної деформації за Н-критерісм} Крускалла-Уолліса

\begin{tabular}{|c|c|c|c|c|c|c|c|c|c|c|c|}
\hline \multicolumn{12}{|c|}{ Test Statistics $^{\mathrm{a}, \mathrm{b}}$} \\
\hline & $\begin{array}{l}\text { Pi- } \\
\text { ве } \\
\text { нь } \\
\text { ем } \\
\text { па } \\
\text { тії }\end{array}$ & $\begin{array}{c}\text { Сту } \\
\text { пін } \\
\text { ь } \\
\text { за- } \\
\text { дов } \\
\text { оле } \\
\text { нос } \\
\text { ті } \\
\text { ро- } \\
\text { бот } \\
\text { ою }\end{array}$ & $\begin{array}{c}\text { Сту- } \\
\text { пінь } \\
\text { не- } \\
\text { задо } \\
\text { воле } \\
\text { ност } \\
\text { i } \\
\text { ро- } \\
\text { бото } \\
\text { ю }\end{array}$ & $\begin{array}{l}\text { Ay } \\
\text { тоа } \\
\text { гре } \\
\text { сія }\end{array}$ & $\begin{array}{c}\text { Ге- } \\
\text { тер } \\
\text { оаГ } \\
\text { рес } \\
\text { iя }\end{array}$ & $\begin{array}{c}\text { Аг- } \\
\text { рес } \\
\text { ивн } \\
\text { a } \\
\text { по- } \\
\text { вед } \\
\text { інк } \\
\text { а }\end{array}$ & $\begin{array}{l}\text { Су- } \\
\text { пер } \\
\text { ниц } \\
\text { тво }\end{array}$ & $\begin{array}{c}\text { C } \\
\text { пі } \\
\text { в } \\
\Pi \\
\mathrm{p} \\
\mathrm{a} \\
Ц \\
\mathrm{~g}\end{array}$ & $\begin{array}{c}\text { Ко } \\
\text { мп } \\
\text { poм } \\
\text { ic }\end{array}$ & $\begin{array}{c}\text { У } \\
\text { ни } \\
\text { КН } \\
\text { ен } \\
\text { НЯ }\end{array}$ & $\begin{array}{c}\text { Пр } \\
\text { ист } \\
\text { осу } \\
\text { ван } \\
\text { ня }\end{array}$ \\
\hline $\begin{array}{c}\text { Chi- } \\
\text { Squar } \\
\text { e }\end{array}$ & $\begin{array}{c}4,75 \\
0\end{array}$ & $\begin{array}{c}37,74 \\
8\end{array}$ & 15,775 & $\begin{array}{c}35,29 \\
5\end{array}$ & $\begin{array}{c}23,50 \\
7\end{array}$ & $\begin{array}{c}22,61 \\
4\end{array}$ & $\begin{array}{c}32,82 \\
3\end{array}$ & $\begin{array}{c}14,9 \\
79\end{array}$ & $\begin{array}{c}13,34 \\
3\end{array}$ & $\begin{array}{c}1,48 \\
3\end{array}$ & $\begin{array}{c}17,71 \\
3\end{array}$ \\
\hline $\mathrm{df}$ & 2 & 2 & 2 & 2 & 2 & 2 & 2 & 2 & 2 & 2 & 2 \\
\hline $\begin{array}{l}\text { Asym } \\
\text { p. Sig. }\end{array}$ & ,093 & ,000 & ,000 &, 000 &, 000 &, 000 & ,000 & ,001 & ,001 & ,476 &, 000 \\
\hline
\end{tabular}

a. Kruskal Wallis Test

b. Grouping Variable: групи деформація

$(\mathrm{H}=17,713, \mathrm{p} \leq 0,01)$.

Отримані результати вказують на те, що у вихователів з високим рівнем професійної деформації задоволеність власною професійною діяльністю статистично нижча $(\mathrm{H}=37,748, \mathrm{p} \leq 0,01)$, ніж у вихователів 3 серед- показники аутоагресії $(\mathrm{H}=35,295, \mathrm{p} \leq 0,01)$, у порівнянні з вихователями двох інших груп.

У вихователів з високим рівнем професійних деформацій рівень гетероагресії статистично значущо вищий $(\mathrm{H}=23,507, \mathrm{p} \leq 0,01)$, ніж у вихователів з середнім і низьким рівня- 
ми. Крім того, гетероагресія більш властива $\mathrm{i}$ вихователям 3 середнім рівнем професійної деформації, ніж з низьким.

Вихователі з високим рівнем професійних деформацій мають статистичні вищі показники агресивної поведінки $(\mathrm{H}=22,614$, $\mathrm{p} \leq 0,01)$, ніж вихователі з середнім і низьким рівнями.

Для вихователів з високим рівнем професійної деформації більш властиве використання у конфліктних ситуаціях стилю суперництва $(\mathrm{H}=32,823, \mathrm{p} \leq 0,01)$, ніж для вихователів двох інших груп.

Проте стилі співпраці та компромісу, навпаки, більш характерні для вихователів 3 низьким рівнем професійної деформації, ніж для вихователів 3 високим іiі рівнем $(\mathrm{H}=14,979, \mathrm{p} \leq 0,01$ та $\mathrm{H}=13,343, \mathrm{p} \leq 0,01$, відповідно).

Щодо стилю пристосування, то він теж більш характерний для вихователів 3 низьким і середнім рівнями професійної деформації, ніж для вихователів 3 iї високим рівнем $(\mathrm{H}=17,713, \mathrm{p} \leq 0,01)$.

Таким чином, формування емоційного виснаження головним чином пов'язане зі зниженням ступеня задоволення своєю діяльністю, появою руйнівної активності щодо самого себе, зниження вміння спільно обирати в конфліктній ситуації альтернативний варіант, що повністю задовольняє інтереси обох сторін, взаємодіяти на основі взаємних поступок, жертвувати своїми інтересами заради іншого, агресивне ставлення і дії щодо оточуючих, суперництво.

На формування деперсоналізації впливають агресивне ставлення і поведінка щодо оточуючих, суперництво, зниження ступеня задоволеності своєю діяльністю, поява руйнівної активності щодо самого себе, зниження вміння взаємодіяти на основі взаємних поступок, спільно обирати в конфліктній ситуації альтернативний варіант, що повністю задовольняє інтереси обох сторін, жертвувати своїми інтересами заради іншого.

Зростання редукції особистісних досягнень спричинене зниженням ступеня задоволеності змістом і умовами своєї роботи, зниженням суперництва, здорового честолюбства і самовпевненості, зростанням прагнення до компромісу і пристосування, надмірною чутливістю до переживань інших людей.

Підсумовуючи результати кореляційного та порівняльного досліджень, можна припустити, що саме зниження аутоагресії та гетероагресії, суперництва у взаємодії, зокрема конфліктній, з іншими учасниками навчальновиховного процесу, підвищення задоволеності роботою, оволодіння такими стилями конфліктної взаємодії як компроміс і співпраця у вихователів 3 високим рівнем професійної деформації можуть виступати психологічними умовами корекції професійних деформацій.

\section{Висновки та перспективи подальших}

розвідок. Результати емпіричної складової дослідження дозволяють констатувати, що 
професійні деформації вихователів закладів дошкільної освіти - доволі поширене явище: високий і середній їх рівні діагностовано у 16\% та 72\% досліджуваних вибірки відповідно.

Ознаки професійної деформації вихователів проявляється у втраті інтересу та позитивного ставлення до вихованців та інших учасників навчально-виховного, відчутті «перенасиченості» роботою, незадоволеності життям в цілому, психофізичної перевтоми; розвитку емоційної відмежованості та байдужості, формальному виконанні професійних обов'язків без особистісної включеності та співпереживання, а в окремих випадках - прояву негативізму та цинічного ставлення до колег, дітей і їхніх батьків.

На зростання рівня та вираженості ознак професійної деформації у вихователів впливають зростання руйнівної активності щодо самого себе (самозвинувачення, принизливі висловлювання про себе, залежності, байдуже ставлення до свого здоров'я); зниження уміння спільно обирати в конфліктній ситуації альтернативний варіант, що повністю задовольняє інтереси обох сторін, встановлювати перемир'я на основі взаємних поступок.

Ключовими детермінантами професійних деформацій вихователів є: конфліктність, відсутність конфліктної компетентності, гетероагресія та аутоагресія, низький рівень емпатіï, неусвідомлювані або прагматичні мотиви вибору професії, несприйнятливість до новов- ведень, низький рівень комунікативних навичок, відсутність здатності до саморефлексії та саморелаксації, тривожність, інфантилізм, песимізм; контингент (діти, батьки, колеги, адміністрація) та потреба в ефективній взаємодії з усіма; схильність до стереотипізації професійної діяльності і поведінки; робота 3 дітьми; низький престиж професії; стаж роботи; фемінізованість колективу; відсутність часу на розваги чи відпочинок, постійне перебування у стані контролюючого дорослого 3 високим рівнем відповідальності за життя і здоров'я вихованців, що супроводжується пригніченням власних емоцій, станів і їх проявів задля благополуччя інших, дисбаланс між роботою та особистим життям.

Результати дослідження є перспективними для подальших наукових пошуків, які можуть будуть спрямовані на вивчення особистісних чинників детермінант професійних деформацій у вихователів закладів дошкільної освіти, а також вчителів шкіл та викладачів вищих закладів освіти з різними рівнями професійних деформацій.

\section{Перелік використаних джерел:}

1.Сорокин П. А. Общедоступный учебник социологии. Статьи разных лет / Питирим Александрович Сорокин. - М. : Наука, 1994. -560 с.

2.Безносов С. П. Профессиональная деформація личности / С. П. Безносов. - СПб. : Речь, 2004. - 272 с.

3.Боднарчук О. Г. Професійна деформація персоналу як передумова виникнення корупції в Державній кримінально-виконавчій службі України [Електронний ресурс] / О. 
Г. Боднарчук // Часопис Національного університету «Острозька академія». Серія «Право». - 2012. - № 2 (6). Режим доступу : http://www.nbuv.gov.ua/e-journals/ Choasp/2012_2/12bohvsu.pdf

4.Борисова Е. М. Индивидуальность и профессия / Е. М. Борисова, Г. П. Логинова - М. : Знание, 1991. - 78 с.

5.Бойко В. В. Энергия эмоций в общении: взгляд на себя и на других / Виктор Васильевич Бойко. - М. : Филинъ, 1996. - 472 с.

6.Водопьянова Н. Е. Синдром выгорания: диагностика и профилактика / Н. Е. Водопьянова, Е. С. Старченкова. - [2-е изд.]. - СПб. : Питер, 2008. - 336 с. - (Серия «Практическая психология»).

7.Геллерштейн С. Г. Проблемы психотехники на пороге второй пятилетки / Соломон Григорьевич Геллерштейн // История советской психологии труда. Тексты. М. : Изд-во Моск. ун-та, 1983. - С. 76-90.

8.Грановская Р. М. Элементы практической психологии / Р. М. Грановская. - Л. : Изд-во ЛГУ, 1988.- 560 с. 9.Зеер Э. Ф. Психология профессий / Э. Ф. Зеер. - Екатеренбург : ГППУ, 1999. - 280 с.

10.Зеер Э. Ф. Психология профессиональных деструкций : учебное пособие для вузов. / Зеер Э.Ф., Сыманюк Э.Э. - М. : Академический Проект; Екатеринбург : Деловая книга, 2005. - 240 с.

11.Корнеева Л. Н. Профессиональная психология личности / Л. Н. Корнеева // Психологическое обеспечение профессиональной деятельности / Под ред. Г. С.Никифорова. - СПб. : СПбГУ, 1991. - С. 61-84.

12.Марковець О. Л. Психологічні особливості професійного стресу та попередження його виникнення у майбутніх вчителів : автореф. дис. канд. психол. наук: 19.00.07 Марковець Олена Леонідівна / Національний педагогічний університет імені М. П. Драгоманова. К., 2005. -23 c.

13.Рукавишников А. А. Определение психического выгорания // Фетискин Н. П., Козлов В. В., Мануйлов Г. М. Социально-психологическая диагностика развития личности и малых групп. Зеер Э.Ф., Сыманюк Э.Э. - М. : Институт психотерапии, 2002. - 490 с. - С. 357-360.
14.Смирнов С. Д. Индивидуальности студента и преподавателя как факторы построения эффективного учебно -воспитательного процесса / С. Д. Смирнов // Вестник Московского университета. 2008. - № 3. - С. 33-44.

15.Шишкова Г. В. Социологические аспекты детерминант профессиональных деформаций / Г. В. Шишкова // Вестник Уральского государственного университета путей сообщения. - 2014. - № 1 (21). - С. 116-122.

16.Юрченко Е. В. Содержание и методы преодоления профессиональной деформации учителя в работе педагога-психолога: дис. канд. пед. наук / Е. В. Юрченко. Уссурийск, 2000. - 181 с.

17.Holland Y. L. Explorations of a theory of vocational choice / Y. L.Holland // J. Appl. Psychol., 1968. - Vol.52. N1.

18.Parsons F. Choosing a Vocation / Frank Parsons. Boston: Houghton Mifflin Co., 1909. -182 p.

19.Roe A. The psychology of occupations / A.Roe. - N.Y. : Willey, 1956. $-340 \mathrm{p}$.

20.Roe A. The origin of interests / A. Roe, M. Siegelman. Washington: APGA, 1969. - 98 p.

21.Super D. E. Vocational development / D. E.Super. - N. Y., 1957. $-391 \mathrm{p}$ 22.Super D. E. Occupational psychology / D. E.Super, M. Y. Bahn. - London. : Tavistock, 1971. - 209 p.

\section{References (Transliteration):}

1.Sorokin P. A. Obschedostupnyiy uchebnik sotsiologii. Stati raznyih let / Pitirim Aleksandrovich Sorokin. - M.: Nauka, 1994. -560 s.

2.Beznosov S. P. Professionalnaya deformatsIya lichnosti / S. P. Beznosov. - SPb. : Rech, 2004. - 272 s.

3.Bodnarchuk O. G. ProfesIyna deformatsIya personalu yak peredumova viniknennya koruptsIYi v DerzhavnIy krimInalno-vikonavchIy sluzhbI UkraYini [Elektronniy resurs] / O. G. Bodnarchuk // Chasopis NatsIonalnogo unIversitetu «Ostrozka akademIya». SerIya «Pravo». 2012. - \# 2 (6). - Rezhim dostupu: http:// www.nbuv.gov.ua/e-journals/Choasp/2012_2/12bohvsu.pdf 
4.Borisova E. M. Individualnost i professiya / E. M. Borisova, G. P. Loginova / - M. : Znanie, 1991. - 78 s.

5.Boyko V. V. Energiya emotsiy v obschenii: vzglyad na sebya i na drugih / Viktor Vasilevich Boyko. - M. : Filin', 1996. $-472 \mathrm{~s}$.

6.Vodopyanova N. E. Sindrom vyigoraniya: diagnostika i profilaktika / N. E. Vodopyanova, E.S. Starchenkova. - [2e izd.]. - SPb. : Piter, 2008. - 336 s. - (Seriya «Prakticheskaya psihologiya»).

7.Gellershteyn S. G. Problemyi psihotehniki na poroge vtoroy pyatiletki / Solomon Grigorevich Gellershteyn // Istoriya sovetskoy psihologii truda. Tekstyi. - M. : Izd-vo Mosk. un-ta, 1983. - S. 76-90.

8.Granovskaya P. M. Elementyi prakticheskoy psihologii / P. M. Granovskaya. - L.: Izd-vo LGU, 1988.- 560 s.

9.Zeer E. F. Psihologiya professiy / E. F. Zeer. Ekaterenburg: GPPU, 1999. - 280 s.

10.Zeer E.F. Psihologiya professionalnyih destruktsiy: uchebnoe posobie dlya vuzov./ Zeer E.F., Syimanyuk E.E. - M.: Akademicheskiy Proekt; Ekaterinburg: Delovaya kniga, 2005. - $240 \mathrm{~s}$.

11.Korneeva L. N. Professionalnaya psihologiya lichnosti /

L. N. Korneeva // Psihologicheskoe obespechenie professionalnoy deyatelnosti / Pod red. G. S.Nikiforova. SPb. : SPbGU, 1991. - S. 61-84.

12.Markovets O. L. PsihologIchnI osoblivostI profesIynogo stresu ta poperedzhennya yogo viniknennya u maybutnIh vchitellv : avtoref. dis. kand. psihol. nauk: 19.00.07 Markovets Olena LeonIdIvna / NatsIonalniy pedagogIchniy unIversitet ImenI M . P . Dragomanova . - K., 2005. - 23 s. 13.Rukavishnikov A. A. Opredelenie psihicheskogo vyigoraniya // Fetiskin N. P., Kozlov V. V., Manuylov G.

M. Sotsialno-psihologicheskaya diagnostika razvitiya lichnosti i malyih grupp. - Moskva: Institut psihoterapii, 2002. -490 s. - C. 357-360.

14.Smirnov S. D. Individualnosti studenta i prepodavatelya kak faktoryi postroeniya effektivnogo uchebnovospitatelnogo protsessa / S. D. Smirnov // Vestnik Moskovskogo universiteta. 2008. - \# 3. - S. 33-44.

15.Shishkova G. V. Sotsiologicheskie aspektyi determinant professionalnyih deformatsiy / G. V. Shishkova // Vestnik Uralskogo gosudarstvennogo universiteta putey soobscheniya. - 2014. - \# 1 (21). - S. 116-122.

16.Yurchenko E. V. Soderzhanie i metodyi preodoleniya professionalnoy deformatsii uchitelya $\mathrm{v}$ rabote pedagogapsihologa: dis. kand. ped. nauk / E. V. Yurchenko. Ussuriysk, 2000. - $181 \mathrm{~s}$.

17.Holland Y. L. Explorations of a theory of vocational choice / Y. L.Holland // J. Appl. Psychol., 1968. - Vol.52. N1.

18.Parsons F. Choosing a Vocation / Frank Parsons. -Boston: Houghton Mifflin Co., 1909. -182 p.

19.Roe A. The psychology of occupations / A.Roe. - N.Y. :

Willey, 1956. $-340 \mathrm{p}$.

20.Roe A. The origin of interests / A. Roe, M. Siegelman. -

Washington : APGA, 1969. - 98 p.

21.Super D. E. Vocational development / D. E.Super. - N. Y., 1957. $-391 \mathrm{p}$

22.Super D. E. Occupational psychology /D. E.Super, M. Y. Bahn. - London. : Tavistock, 1971. - 209 p.

\section{Polishchuk Oksana}

PhD (Psychology) associate professor at the department of psychology, Yuriy Fedkovych Chernivtsi National University (Ukraine)

\section{Koltunovych Tetiana}

PhD (Psychology) the assistant at the department of pedagogy and psychology of preschool education, Yuriy Fedkovych Chernivtsi National University (Ukraine)

\section{FEATURES OF EMOTIONAL EXPRESSION MENTORS OF PRESCHOOL TEACHERS WITH DIFFERENT LEVELS OF PROFESSIONAL DEFORMATION}

\section{ABSTRACT}

The article analyzes the peculiarities of professional deformations, clarifies the defining characteristic of the concept of "professional de- 
formation of the educator" and outlines the key determinants of professional deformation of educators. It covers also the empirical research of professional deformations among preschool teachers, and their connection with empathy, aggressiveness and behavior in conflict situations.

On the basis of the realized theoretical analysis of scientific sources, the definitions of the concept of "professional deformation of the educator" as a set of destructive changes of his personality, determined by the specifics of the activity, the stage of professionalization, objective and subjective factors, were clarified.

The key determinants of professional deformities of educators are: conflict, lack of conflict competence, heteroaggression and autoaggression, low level of empathy, unconscious or pragmatic motives for choosing a profession, immunity to innovations, lack of communicative skills, self-reflexive ability and self-relaxation, anxiety, infantilism, pessimism; the contingent (children, parents, colleagues, administration) and the need for effective interaction with everyone; propensity for stereotyping of professional activity and behavior; work with children (contributes to the tendency to simplify, clarify); low prestige of the profession; work experience; feminization of the team; absence of the right to mistake, time for entertainment or rest, permanent staying in a supervising adult with a high level of responsibility for the life and health of the pupils, accompanied by inhibition of their own emotions, states and their manifestations for the well-being of oth- ers, personality disorder, violation of the balance "work -privacy".

On the basis of the obtained results it was determined that professional deformations of preschool teachers are quite common; educators with a high level of professional deformity are characterized by dissatisfaction with their own professional activities, high rates of autoaggression and heteroaggression, the style of competition used in conflict situation. It was found out that the growth of the level and severity of signs of professional deformation among educators is influenced by the growth of destructive activity in relation to oneself; reducing the ability to jointly choose an alternative option in a conflict situation, increasing the desire to achieve their interests, reducing the level of satisfaction with the content and conditions of their work, aggressive attitude to others.

It is assumed that the reduction of autoaggression and heteroaggression, competition in interaction, in particular conflict with other participants in the educational process, increasing job satisfaction, mastering such styles of conflict interaction as a compromise and cooperation of educators with a high level of professional deformation can act as psychological conditions of correction of the professional deformation.

Keywords: professional deformation, professional burnout, aggressiveness, conflict.

(С) Полішук О. М., Колтунович Т. А. 


\section{Полищук Оксана Николаевна}

Кандидат психологических наук, доцент кафедры психологии, Черновицкий национальный университет имени Юрия Федьковича, г. Черновцы (Украина)

\section{Колтунович Татьяна Анатольевна}

Кандидат психологических наук, ассистент кафедрь педагогики и психологии дошкольного образования, Черновиџкий национальный университет имени Юрия Федьковича, г. Черновиьь (Украина)

\section{ОСОБЕННОСТИ ЭМОЦИОНАЛЬНЫХ ПРОЯВЛЕНИЙ У ВОСПИТАТЕЛЕЙ С РАЗНЫМИ УРОВНЯМИ ПРОФЕССИО- НАЛЬНЫХ ДЕФОРМАЦЫЙ}

Аннотация. В статье проанализированы особенности профессиональных деформаций, уточнена дефинитивная характеристика понятия «профессиональная деформация воспитателя» и обозначены ключевые детерминанты профессиональных деформаций воспитателей. Представлены результаты эмпирического исследования профессиональных деформаций у воспитателей дошкольных учебных заведений, и их связи с эмпатией, агрессивностью и поведением в конфликтных ситуациях.

На основе проведенного теоретического анализа научных источников подано дефинитивную характеристику понятия «профессиональная деформация воспитателя» как совокупность деструктивных изменений его личности, обусловленных спецификой деятельности, этапом профессионализации, объективными и субъективными факторами.

Ключевыми детерминантами профессиональных деформаций воспитателей явля- ются: конфликтность, отсутствие конфликтной компетентности, гетеро- и аутоагрессия, низкий уровень эмпатии, неосознаваемые или прагматические мотивы выбора профессии, невосприимчивость к нововведениям, отсутствие коммуникативных навыков, способности к саморефлексии и саморелаксации, тревожность, конфликтность, инфантильность, пессимизм; контингент (дети, родители, коллеги, администрация) и потребность в эффективном взаимодействии со всеми; склонность к стереотипизации профессиональной деятельности и поведения; работа с детьми (которая способствует формированию склонности к упрощению), низкий престиж профессии; стаж работы; феминизованность коллектива; отсутствие права на ошибку, времени на развлечения или отдых, постоянное пребывание в состоянии контролирующего взрослого с высоким уровнем ответственности за жизнь и здоровье воспитанников, которое сопровождается угнетением мыслей, личностная неустроенность, нарушение баланса системы «работа - личная жизнь».

На основе полученных результатов установлено, что профессиональные деформации воспитателей учреждений дошкольного образования есть довольно распространенным явлением. Воспитателям с высоким уровнем профессиональных деформаций свойственны неудовлетворенность собственной профессиональной деятельностью, высокие показатели ауто- и гетероагресии, использование в кон- 
фликтных ситуациях стиля соперничества. Выяснено, что на рост уровня и проявления признаков профессиональной деформации у воспитателей, влияют: рост разрушительной активности в отношении самого себя; снижение умения совместно выбирать в конфликтной ситуации альтернативный вариант, рост стремления добиться своих интересов, снижение уровня удовлетворенности содержанием и условиями своего труда, агрессивное отношение к другим.

Сделано предположение, что именно снижение ауто- и гетероагресии, соперничества во взаимодействии, в частности конфликтной, с другими участниками учебновоспитательного процесса, повышение удовлетворенности работой, овладение такими стилями конфликтного взаимодействия как компромисс и сотрудничество у воспитателей с высоким уровнем профессиональной деформации могут выступать психологическими условиями коррекции профессиональных деформаций.

Ключевые слова: профессиональные деформации, профессиональное выгорание, агрессивность, конфликтность.
Дата отримання статті: 11.03.2019 Дата рекомендації до друку: 25.03.2019 Дата оприлюднення: 17.04.2019 